\title{
UNPACKING ADAPTATION: THE FEMALE INHERITANCE MOVEMENT IN HONG KONG*
}

\author{
Rachel E. Stern ${ }^{+}$
}

\begin{abstract}
In 1994, after a year of intense activism by indigenous women and their urban supporters, indigenous women in the New Territories of Hong Kong were legally allowed to inherit land for the first time. In pushing for legislative change, the female inheritance movement adopted key ideas-gender equality, human rights and a critique of patriarchy-from a global vocabulary of feminism and human rights. This article examines this rights frame to understand how, if at all, activists modified international conceptions of discrimination and rights to fit Hong Kong. Overall, the ideology was not fundamentally altered or adapted, but indigenized by local activists through the use of local symbols. More deep-rooted change was not necessary for two reasons: First, in the pre-handover moment, rights arguments derived political currency from their association with an international community. Also, critical movement participants, here termed translators, helped encompass the indigenous women's individual kinship grievances within a broader movement based on rights.
\end{abstract}

In 1993, Hong Kong was engulfed in a debate over female inheritance in the New Territories, a relatively rural area just across the border from Mainland China. ${ }^{1}$ Female inheritance was discussed on talk shows, in classrooms and around dinner tables. The issue at hand was whether to amend the 1910 New Territories Ordinance to allow indigenous women to inherit land. Unlike urban Hong Kong residents governed by British colonial law, indigenous residents were subject to a colonial version of Qing dynasty Chinese customary law that forbids female inheritance. $^{2}$

As the controversy over female inheritance unfolded, the Legislative Council, the legislative body in charge of ratifying the amendment, was a natural site for activism. In a series of dramatic demonstrations, a coalition of women's groups squared off against the Heung Yee Kuk, an organization representing indigenous villagers. ${ }^{3}$ Under banners proclaiming "ㅇ $=\widehat{ }$ " " and "gender equality," women's groups argued that male-only inheritance was a form of sexual discrimination and, more broadly, a violation of human rights. These broad claims about rights were illustrated by the stories of six indigenous women who stepped forward to protest their disinheritance. These indigenous women did not wear " $O=\$$ " oversized "Hakka hats" of farm workers and sang folk laments about injustice. ${ }^{4}$

The female inheritance movement, as it came to be known, shows how rights language diffuses across borders. ${ }^{5}$ Although rights language is clearly used cross-culturally and crossnationally, the diffusion process is understudied (Snow and Benford 2000: 628; Kriesi,

\footnotetext{
* Research for this article was supported by a grant from Wellesley College. The article has benefited from thoughtful comments from Kevin O’Brien, Chris Ansell, Taeku Lee and three anonymous reviewers. Special thanks to Sally Merry for support in developing this project as well as participants in the movement for sharing their experiences.

$\dagger$ Rachel Stern is a Ph.D. student in political science at the University of California, Berkeley. Please direct correspondence to rstern@berkeley.edu
}

(C) Mobilization: An International Journal 10(3): 421-439 
Koopmans, Duyvendak, and Giugni 1995: 181). ${ }^{6}$ The literature assumes a process of adaptation where conceptions of gender equality and rights rooted in feminist texts and United Nations covenants are made relevant to a local context. Scalmer (2002: 1), for example, notes an "emergent consensus that ... diffusion rests upon a sustained labor of cultural, intellectual, and practical translation.",

But how deep does "cultural, intellectual, and practical translation" run? Did Hakka hats symbolize a difference in the way rights were understood in Hong Kong? Or were they costumes that lent the movement a Hong Kong flavor? More broadly, can we distinguish between instances of fundamental change and local window dressing of ideas borrowed from elsewhere? Using the female inheritance movement as a case study, my goal is to unpack "adaptation" and be more precise about the nature and extent of change.

In doing so, I suggest a continuum between adoption and adaptation. Adaptation is fundamental change to the content of mobilization (ideas and themes), the form of organization (the structure of the social movement) or the form of action (tactics). ${ }^{8}$ One example of adaptation is Maoism. In bringing Marxism-Leninism to China, Mao Zedong changed core elements of the ideology. The revolutionary vanguard was no longer Marx's urban proletariat, but the Chinese peasantry. Unlike Marx, Mao also pioneered continuous revolution a way to prevent reossification of the class structure (Tarrow 1998: 109; Meisner 1999: 44; see also Wylie 1980). Adoption is the opposite pole of adaptation: imitation of ideas, structures or tactics imported without change.

Indigenization lies between adoption and adaptation. It is "innovation at the margins" in which activists introduce new, creative elements while key ideas, structures, or tactics remain the same (Tarrow 1998: 102). In 1996, Belgians protesting sexual crimes against children, for example, chose a familiar form of protest - the demonstration - but wore white to symbolize purity (Tarrow 1998: 102). Often, innovation at the margins localizes collective action enough to counter criticism that activism is a foreign import. Here, I use indigenization to describe the use of local symbols to gain legitimacy for ideas, forms of organization or tactics that originate elsewhere. This is not to belittle indigenization. In itself, the process of indigenization is creative, contested and significant to movement participants. It is a form of what Chabot and Duyvendak call collective appropriation, in which "receiving communities alter their strategies and collective identities in order to apply the diffusion item in their own settings" (2002: 708).

In large part, this is an argument for precision. Indigenization and adaptation are often used interchangeably. Yet there is a vital difference between introducing local elements (indigenization) and pioneering new forms (adaptation). While the line between adaptation and indigenization is debatable, the distinction is worthwhile because the potential rarity of true adaptation makes instances of fundamental change all the more significant.

The female inheritance movement is a case study of indigenization rather than adaptation. Key ideas - gender equality, human rights and critique of patriarchy - were borrowed from a global vocabulary of feminism and rights. However, this was not a case of cultural imperialism or the blind copying of foreign ideas. Although rights and equality, the two most important themes of the movement, were understood in Hong Kong much as they were globally, these ideas were indigenized as they were expressed by local activists using local symbols.

Here, I am concerned with not only the existence of indigenization, but the process of indigenization: the way movement participants crafted, reworked, and understood rights language. Focusing on process means focusing on interactions between individuals and how those interactions led the movement towards indigenization rather than adoption or adaptation. In this retelling, a few people stand out as key links between rights language and the indigenous women themselves. These individuals, called translators (Merry and Stern 2005), took the women's kinship grievances and reframed them in the more generalized language of human rights. By bringing rights language to a new audience and applying it in a new way, translators were an integral part of indigenization. More extensive adaptation was not necessary because of the particular moment in Hong Kong history. In 1993-1994, the rights frame derived political 
currency from its association with international institutions and an international community. For the wider public, lack of adaptation was what made rights language locally appealing.

\section{CROSS-NATIONAL DIFFUSION OF FRAMES AND THE FEMALE INHERITANCE MOVEMENT}

The use of rights language in the female inheritance movement is a case study of how ideas move across borders, also known as the cross-national diffusion of frames. To start, it is worthwhile to briefly survey the literature on framing to see where the female inheritance movement has something new to offer. Snow and Benford (2000: 614) define a collective action frame as "action-oriented sets of beliefs and meanings that inspire and legitimate the activities and campaigns of a social movement organization." Frames, created by social movement organi-zations or activists, offer a shared understanding of the problem as well as an agenda for change (ibid.). This creative process is contested and ongoing, both because actors struggle over mean-ing within the movement and because framers must contest alternative frames offered by the opposition. As social movement scholars have pointed out, frames are not created from scratch, but rooted in existing cultural understandings (Hart 1996; see also Tarrow 1992 and Zald 1996). By definition, however, a frame also offers a cultural critique because it involves the public expression of dissenting views (Thornton 2002: 662). As frames gain currency, they can push forward cultural change as people come to understand a problem in different terms (Tarrow 1992: 189).

Rights discourse is a master frame, defined as a frame "sufficiently broad in interpretive scope, inclusively, flexibility and cultural resonance" to be used by distinctive movements (Snow and Benford 2000: 619). Like other master frames, rights language travels well and is often a powerful tool for those with few resources. McCann (1994), for example, found that rights language in the American pay equity movement helped solicit public support and name a "long-experienced injustice in new, compelling and sensible terms" (89). As Martha Minnow writes, "rights pronounced by courts [or international institutions like the United Nations] become possessions of the dispossessed. . . Legal language, like a song, can be hummed by someone who did not write it and changed by those for whom it was not intended" (quoted in McCann 1993: 733).

In dealing with the cross-national diffusion of frames, scholars have been primarily concerned with the circumstances under which diffusion is most likely and the mechanisms by which diffusion takes place (see McAdam and Rucht 1993; Della Porta and Kriesi 1999; Snow and Benford 1999; Snow and Benford 2000; and Best 2001). Snow and Benford (1999), for example, present a broad typology based on the relative engagement of adopters and transmitters of a frame. ${ }^{9}$ The underlying assumption of work on cross-national diffusion is that frames are most likely to diffuse across similar cultures because diffusion requires a "minimal identification of adopter with transmitter" (McAdam and Rucht 1993: 60). If cultural differences loom too large, the frame will be dismissed as culturally irrelevant. The corollary is that frames are routinely "reformulated to take local culture and social structure into account" (Best 2001: 10; Chabot and Duyvendak 2002: 707). As Sperling (2001: 1158) puts it, "no "traveling discourse" or set of terms, values, and ideas, feminism included, is received and used in identical fashion everywhere it goes."

It seems like common sense that ideas are modified to local circumstances depending on their usefulness. However, the female inheritance movement shows there is a spectrum of modification. Most often, ideas are indigenized to make them familiar without changing core concepts. Yet indigenization is not always necessary. At times, as in the pre-handover moment, utility is derived from otherness, or precisely the lack of adaptation to local circumstances. 


\section{THE FEMALE INHERITANCE MOVEMENT}

Before returning to frame diffusion, it is helpful to sketch how the female inheritance movement unfolded. Often, social movements hinge on the participation of a single leader or risk-taker, sometimes called a political entrepreneur (O'Brien and Li 2004; Diamant 2005). While the success of the female movement hinged on a serendipitous discovery (discussed below), it started with Lai-sheung Cheng. Cheng was the first indigenous woman to step forward and played a vital role in convincing other indigenous women to tell their stories. ${ }^{10}$

When Cheng's father died without a will, a common occurrence in the New Territories, and her two brothers inherited the family's two-story home in Yuen Long, a town in the New Territories. ${ }^{11}$ In May 1991, Cheng's brothers decided to sell the house to a private developer. The only problem was that Cheng was still living on the second floor. Cheng refused to leave unless she was given a share of the proceeds from the sale, citing a Qing dynasty custom that allows unmarried women to reside indefinitely in the family's home after a father's death (South China Morning Post, 23 Aug. 1993; Cheng interview 2003). For the next two years, Cheng was harassed by the buyer of the house who tried to force her to leave. The buyer routinely broke into the house, once smearing excrement and urine around the interior and, on another occasion, releasing mice (The Sunday Telegraph, 24 Oct. 1993; Cheng interview 2003).

Fed up, Cheng decided to make her story public. She wrote a letter to Chris Patten, then governor of Hong Kong, claiming that, in her words, "I was persecuted because of [Chinese customary] law" (Cheng interview 2003). ${ }^{12}$ Not content with alerting Governor Patten, Cheng also wrote a letter to the Chinese newspaper Oriental Daily. Oriental Daily did not publish the letter, but someone at the paper put Cheng in touch with Linda Wong, a social worker at the Hong Kong Federation of Women's Centres. ${ }^{13}$ Cheng told Linda Wong over the phone that she knew several other indigenous women in a similar situation, including a patient at Cheng's Chinese medicine clinic. ${ }^{14}$ Cheng and several other indigenous women met with Wong for the first time in late 1993 and began to publicize their stories (Wong interview 2003). The first formal step, they decided, was to file a complaint at the Complaints Division of the Office of Members of the Legislative Council (Wong interview 2003).

As the indigenous women were organizing, prohibition of female inheritance in the New Territories was gaining prominence as a political issue. Legally, the problem stemmed from Hong Kong's dual legal system regarding land. While Hong Kong Island and Kowloon, the two other regions of Hong Kong, were governed by a common law legal system imported from Britain, the New Territories fell under the 1910 New Territories Ordinance, which recognizes Chinese customary land law. Although the original legislation made it sound like courts had the option of using Chinese customary law to resolve land cases, ("the courts have the power to enforce Chinese custom or customary right"), the Tang v Tang decision (1970) established that application of Chinese custom to New Territories land cases was mandatory (Selby 1991: 48; Loh 1997). ${ }^{15}$

While discrimination against New Territories' women had been on the radar screen of women's groups for some time, the specific issue of female inheritance took on increased importance after a 1991 shadow report by the Hong Kong Council of Women on compliance with the International Covenant on Civil and Political Rights (ICCPR). The most important contribution of this report had nothing to do with the content. While doing research, one of the authors discovered that the jurisdiction of the New Territories Ordinance was based on territory, not on indigenous identity. In other words, Chinese customary law applied to all residents of the New Territories, not just indigenous villagers. Even women living in public housing estates or private flats were ineligible to inherit property (Petersen 1996: 341; Jones interview 2003). When this news broke in the Chinese newspaper Ming Pao on September 6, 1993, it immediately created a crisis for the government (Wong 2000: 299; see also Fischler 2000: 215) ${ }^{16}$

The indigenous women took advantage of the political opening created by this fortuitous discovery to begin demanding equal inheritance rights. On October 3, 1993, they lodged a 
complaint at the Complaints Division of the Legislative Council. Less than a week later, the Legislative Council passed a non-binding motion calling for female inheritance in the New Territories (South China Morning Post, 14 Oct. 1993). Around this time, the indigenous women and Linda Wong formed the Anti-Discrimination Female Indigenous Residents Committee. ${ }^{17}$

After the initial motion debate and the formation of the Residents Committee, events began unfolding rapidly. ${ }^{18}$ Inside the Legislative Council, Legislative Councilor Christine Loh took up the female inheritance cause. Loh, educated in both Hong Kong and England, was appointed by Governor Patten to the Legislative Council in 1992. She says the issue appealed to her because she thought it was "very odd" that indigenous women had "less rights" than everyone else in Hong Kong (Loh interview, June 2003). On January 31, 1994, Loh submitted an amendment to allow female indigenous women to inherit property.

For several months after Loh submitted her amendment, things were quiet. The Heung Yee Kuk, the organization representing indigenous villagers, relied on old-style colonial politics and assumed the amendment would never receive government support. Yet on March 10, the government announced it would not oppose Loh's amendment. This came as quite a surprise because the government had long courted the support of Kuk members, mostly major landholders, for development in the New Territories. Some Kuk members felt that the government sold them out because the government was no longer as reliant on Kuk support (South China Morning Post, 27 March 1994). The Kuk's pro-Beijing stance and opposition to Governor Patten's political reforms may also have played a role in the government's change in policy (South China Morning Post, 27 March 1994).

In response to the change in the government's position, the Kuk organized a rally on March 22, attended by over 1,200 Kuk supporters (South China Morning Post, 23 March 1994). During the rally, twenty incensed indigenous villagers broke through security barriers outside the Legislative Council building. They attacked demonstrators for female inheritance rights, ripped up banners, threw water bottles and shouted curses (South China Morning Post, 23 March 1994; Tse interview June, 2003). Lee Wing-tat, a legislative councilor caught in the fray, fell to the ground after a punch to the back.

Just after March 22, twelve women's groups formed the Coalition for Equal Inheritance Rights to fight for women's inheritance rights in the New Territories (Tong 1999: 55-56). Three days later, the Heung Yee Kuk formed the Headquarters for the Protection for the Village and Defense of the Clan (Tong 1999: 58). For the next three months, until the New Territories Land (Exemption) Ordinance - hereafter NTL(E)O — was passed on June 23, 1994, these two groups worked hard to gain support, holding frequent demonstrations and facing off dozens of times.

In both the March 22 rally and subsequent demonstrations, the Heung Yee Kuk positioned themselves as defenders of local tradition and culture. The New Territories is traditionally patrilineal and patrilocal and the Kuk argued that female inheritance would lead to a disintegration of clan identity because land would eventually be owned by non-lineage members (Chan 1998: 45). One English placard used during the demonstrations held the plaintive message, "Why are you killing our culture?" (Chan 1995: 30). In order to be seen as legitimate, the male-dominated Kuk realized that they would need the support of indigenous women. They found women who believed that, in the words of Angela Li York-lan, "[Women] do not think we are discriminated against. We love our traditions. We have the right not to accept any change" (South China Morning Post, 4 April 1994). ${ }^{19}$

At the time, it was an open secret that the strength of Kuk resistance was due to fears that female inheritance would lead to the dismantling of other indigenous rights, particularly the 1972 small house policy (Chan 2003). Under the terms of the small house policy, indigenous male villagers can obtain a 700-square foot piece of land, free of land premium, to build a house within the borders of the village (Chan 2003: 72) ${ }^{20}$ This is a valuable right because houses are often rented or sold at a profit (Hopkinson and Lei 2003: 2; Chan 1999: 238-240). Village elder Bruce Kan even said publicly, "the next thing the government would do is cancel our rights on 
applying for land" (South China Morning Post, 27 March 1994).

The inheritance issue stayed steadily in the public eye from October 1993 (the motion debate) through June 1994 (the passage of the bill) because Kuk members were prone to dramatic action, like beheading a doll representing Governor Patten (South China Morning Post, 18 April 1994). On another occasion, angry villagers threatened to rape Loh if she dared set foot in the New Territories (South China Morning Post, 26 March 1994). When it came to media attention, as Loh put it, "one couldn't have better opponents than the Heung Yee Kuk" (June, interview, June 2003).

Although there were times when the outcome of Loh's amendment was unclear, the issue was pretty much settled by May 1994. The public overwhelmingly supported female inheritance rights, by a margin of $77 \%$ in favor to $9 \%$ opposed (South China Morning Post, 9 May 1994). ${ }^{21}$ There was little sympathy for the Heung Yee Kuk both because the public generally believed in gender equality and because they were resentful of special privileges, like the small house policy, granted to indigenous villagers. By the time of the actual vote on June 22, the result was a foregone conclusion. The NTL(E)O passed easily, with 36 votes in favor, two against and three abstentions (Hong Kong Hansard 1994: 4656).

\section{$q^{\prime}=\oint^{\Uparrow}$ : BUILDING THE MASTER RIGHTS FRAME}

While the female inheritance movement is a compelling story in its own right, I am interested in the process by which local activists used international rights language to create a successful frame for a diverse movement. In public, the female inheritance movement primarily argued that male-only inheritance was an illegal subversion of gender equality. This section offers a detailed account of how this master frame was built, a tricky process considering that the indigenous women themselves initially saw the issue quite differently. Two groups played a key role in bringing rights language to the fore: expatriates and women's groups.

\section{Expatriates}

Through the Hong Kong Council of Women's ICCPR shadow report, expatriates played a critical role in bringing the female inheritance issue to prominence and framing it in terms of legal rights. ${ }^{22}$ Hong Kong's Bill of Rights had just been passed in July 1991 and, in the wake of Tiananmen Square, Hong Kong was newly concerned with civil liberties and discrimination (Petersen 1996; see also Petersen and Samuels 2002: 47-48). The ICCPR report clamed that male-only inheritance was a form of gender discrimination that contravened the newly passed Bill of Rights (Howarth et al. 1991: 16). The ICCPR report further explained that Hong Kong's legislation governing succession did not apply to New Territories women and, as a result, women living in the New Territories were legally barred from inheriting land (Howarth, Jones, Peterson, and Samules 1991: 14).

Expatriates pushed female inheritance as an international legal issue. In the ICCPR shadow report, the Hong Kong Council of Women argued that male-only inheritance violated both the Convention on the Elimination of Discrimination Against Women (CEDAW) and the ICCPR (Howarth et al. 1991: 12). The report clearly stated that male-only inheritance "should have been declared unlawful long ago, as [it is] contrary to Article 26 of the ICCPR" and is "in conflict with the principle of equality between sexes contained in the internationally accepted Declaration of Elimination of Discrimination Against Women" (Howarth 1991: 16, 12). The shadow report also included a well-reasoned argument as to why male-only inheritance was not protected by either the Joint Declaration or the Basic Law, the two documents outlining the terms of the handover (Howarth et al. 1991: 16-17). These domestic and international legal arguments were critical both because they provided an intellectual framework for the female inheritance movement and helped clear up confusion about the dual legal system. The government could no 
longer say, as the attorney general claimed in 1986, that it was "not aware of any provisions of [Hong Kong] law which discriminate against women" (quoted in Lui 1997: chapter 3, 5).

This emphasis on international law in the ICCPR shadow report stemmed from the background of the authors. The four authors were all expatriate women with strong academic backgrounds, some of whom dealt with international law professionally. Like the larger Hong Kong Council of Women, they were from the United States, Britain, or Australia and spoke English fluently, if not as a first language. They saw denying women inheritance rights in international terms, as a violation of a woman's human right to protection from gender discrimination. Still, these expatriates were not external agents, but residents of Hong Kong who cared deeply about local politics. As found in case studies elsewhere, they were an important "network bridge," making connections between a specific situation and a broader global discussion of rights (Rothman and Oliver 1999: 43).

\section{Women's Groups}

In contrast to the expatriates' English language discussion of legal rights, local women's groups mostly focused on gender equality and largely discussed the issue in Cantonese. ${ }^{23} \mathrm{~T}$ shirts and banners from the movement often carried the simple slogan " $+=\widehat{O}$. ." In keeping with this theme, one women's group issued a statement that

Based on the principle of equality, land inheritance right is the right of every indigenous inhabitant. If women inhabitants are not entitled to it because of their gender, it is blatant discrimination, something we cannot accept (quoted in Lee 2000: 250).

The women's groups treated gender equality as a self-evident tenet and, for the most part, saw no need to justify it in terms of law. When they did talk about the law, women's groups borrowed their arguments and even their language from the ICCPR report. One AAF publication directly quotes the Hong Kong Council of Women report, saying male-only inheritance rights: "should have been declared unlawful long ago, as they are contrary to Article 26 of the ICCPR" (AAF 1993: 14).

This framing of the problem made an explicit connection between gender equality and modernity, a theme later picked up by the Legislative Council. Male-only inheritance was "archaic and out of step with society's development" (AAF 1993: 14). The Hong Kong Women Christian Council went as far as to say "gender equality is a shared goal of the modern world" (quoted in Wong 2000: 192). This was the only arena that also discussed male-only inheritance as a product of patriarchy. One group accused the Heung Yee Kuk of "patriarchial hegemony" (Wong 2000: 192). ${ }^{24}$ Another group suggested that the majority of indigenous women were not aware of their oppression because of "patriarchial socialization. . . . A harmony that conceals injustice is not one to be applauded" (quoted in Lee 2000: 250-251).

\section{Adoption, Not Adaptation}

Chabot and Duyvendak (2002) criticize the assumption that diffusion is always a top-down process involving the outward spread of foreign ideas or methods. While it is clearly true that diffusion is neither unidirectional nor purely imitative, it is difficult to escape the familiarity of the rights frame described above. The ideology behind the female inheritance movement, including conceptions of gender equality, patriarchy and human rights, were borrowed from abroad. Gender inequality based on a critique of patriarchy, for example, is a standard American feminist message. There was no attempt to create a hybrid "Hong Kong" version of rights in which gender equality or patriarchy came to have a different meaning. Although applied in a new place, these concepts retained their grounding in American and European philosophical 
ideas about individualism, choice, autonomy and equality. Although I am more concerned with frames than tactics, the women's groups techniques of activism - demonstrations, petitions and meetings - are also familiar from American and European feminism, as is the $q=\hat{\gamma} \operatorname{logo}$.

Lack of adaptation (lack of fundamental change to the ideas and themes used in the movement) becomes clearer in contrast to other cases of cross-national diffusion. Yunxiang Yan (1997), for example, shows the degree to which McDonald's changed in response to a new cultural context. In Beijing, people linger over their meals to chat with friends and enjoy "Americana and the promise of modernization" (41). Taking the "fast" out of "fast food" transforms the McDonald's experience. Yan's case study shows how much ideas and institutions can change to adapt to new circumstances.

Yet the rights framework used in the female inheritance movement was not imposed by outsiders, but chosen by a movement that was led by Hong Kong women and primarily conducted in Cantonese. As Watson argues about McDonald's, perhaps rights language is a "third culture," one "oriented beyond national boundaries" (Featherstone, quoted in Watson 1997: 11). It is possible that a generation of Hong Kong women grew up with Hong Kong feminism just as they grew up with McDonald's. Perhaps some had limited the knowledge that the golden arches or $+={ }^{\lambda}$ was ever used anywhere else.

However, lack of adaptation requires further explanation. Why was the female inheritance movement successful despite a failure to adjust their frame to local circum-stances? The answer has several parts: a unique historical moment, reliance on indigenization and the presence of translators within the movement.

\section{THE PRE-HANDOVER MOMENT}

The success of the global rights framework cannot be separated from pre-handover politics in Hong Kong. In 1993, the UN had just appointed the first High Commissioner for Human Rights, a sign of worldwide attention to human rights (Foot 2000: 11). Hong Kong citizens were simultaneously looking back to the 1989 Chinese crackdown at Tiananmen Square and forward to the 1997 handover to China. The 1991 passage of the Bill of Rights, based on the ICCPR, encouraged everyone, including women, to think in terms of human rights (Petersen and Samuels 2002: 24). Greater awareness of human rights coincided with democratic reforms, particularly Patten's 1992 reform package and the 1991 introduction of direct elections to the Legislative Council. ${ }^{25}$ Democratization, particularly the introduction of directly elected representatives in the Legislative Council, also led to increased attention to local problems. ${ }^{26}$

In Hong Kong, support for rights was politically tied to post-handover concern about democratization and the rule of law. This was a time when Hong Kong was routinely dis-cussed in debates about China, Tiananmen and human rights. A 1992 bill introduced to the U.S. Congress by Nancy Pelosi and George Mitchell, for example, called for renewal of China's Most Favored Nation status only if China "adhered to the Joint Declaration on Hong Kong" (Foot 2000: 133). Hong Kong democrats took advantage of the attention and used international documents to enhance their own legitimacy and put pressure on Beijing. ${ }^{27}$ Writing in 1996, Martin Lee, a Legislative Councilor and a well-known democracy advocate, cited international law as protection from future infringements on individual rights: "the Joint Declaration specifically decrees that the ICCPR, from which the Bill of Rights is copied almost word for word, shall remain in force after 1997" (Lee 1996: 169). Changing male-only inheritance meant validating arguments about rights and their place in law, arguments with political ramifications for post-handover Hong Kong. For the female inheritance movement, this was a political opportunity. Democrats and, more broadly, anyone concerned about post-handover freedoms were favorably disposed towards rights arguments.

Because of their political salience, arguments about rights were a major theme in the Legislative Council debates on the NTL(E)O. Christine Loh was one of the prime advocates of 
the rights argument because she primarily saw female inheritance in rights terms (Loh interview 2003). What, Loh asked rhetorically during the motion debate, "would justify excluding the wives and daughters of indigenous villagers from the rights they are guaranteed to under the Bill of Rights and under the ICCPR?” (Hong Kong Hansard 1993: 270). Legislator Anna Wu, herself a lawyer, also picked up the connection between female inheritance and international law, echoing the arguments made in the shadow ICCPR report. In a December 1993 letter to members of the Bills Committee, Wu wrote: "The 1976 extension of the ICCPR to Hong Kong and the 1991 enactment of the Bill of Rights Ordinance should have cast serious doubt on the continuing validity of the system established by the NTO (New Territories Ordinance)" (Wu 1993: 1).

For legislators, there were two appealing aspects of international law. First, international law could be used to shame the government into action. In question and answer sessions with government representatives, legislative council members occasionally inquired about international covenants as a way of holding the government responsible to the ideals expressed in UN documents (Hong Kong Hansard 1993: 156-157 and 159-160). The other appealing aspect of international law was its perceived connection to modernity. In the debate over the passage of the NTL(E)O, Legislator Fung called it "both out of date and inappropriate to deprive women of their land rights," particularly because the Bill of Rights, the ICCPR, and CEDAW all state that all citizens should be equal before the law (Hansard 1994: 4547).

Other supporters of the bill argued that Hong Kong could not be a modern, international city as long as it had laws that discriminated against women. As one legislator put it, "Hong Kong is a prosperous and progressive metropolis. The fact that the indigenous women of the New Territories are still openly discriminated against is a disgrace for the people of Hong Kong” (Hansard 1994: 4565). Many felt that the Heung Yee Kuk's rowdy behavior and verbal abuse left them with no choice but to support the NTL(E)O. Legislator Anna Wu remembers it as a choice between the "law of the jungle" and "civilization" (Wu interview 2003). Others made an explicit connection between the Kuk's behavior and support for the NTL(E)O:

\footnotetext{
When the twentieth century is coming to a close, that someone should so shamelessly and overtly threaten to rape is indeed a shame on this modern international city of Hong Kong. Today members of this Council must use their vote to remove such a stigma (Hong Kong Hansard 1994: 4542).
}

In this pre-handover moment, there was no need for adaptation. A rights frame successfully cast the female inheritance movement as a form of what O'Brien (1996) calls "rightful resistance." Like rightful resistance elsewhere, the movement used the "rhetoric and commitments of the powerful," in this case membership in UN regimes and statements about gender equality, to exploit divisions among elites (O'Brien 1996: 32). By couching claims in terms of international law and rights, the movement chose an "aspirational view" of the colonial government (O'Brien 1996:32) rather than a direct critique, a choice that made it politically feasible for the Executive Council to support Loh's amendment. In Scott's terms, this was a classic "critique within the hegemony" in which a movement adopted the ideological terms of the elite in order to be effective (1990: 106).

In addition, the frame was successful because support for rights were so strong that not even opponents of the bill dared question the tenet of gender equality (Lee 2000: 248). Even Heung Yee Kuk Chairman Lau Wong-fat maintained that the indigenous women "are not actually treated unequally. In fact, they are equal in other respects. Many of them may even often bully their husbands" (Hong Kong Hansard 1994: 4559). While Hong Kong residents may have been unaware of the specifics of the ICCPR and CEDAW, opinion polls reflected a widespread perception that male-only inheritance was a glaring injustice that needed to change. The rights frame was already, in Strang and Soule's phrase, "rendered salient, familiar and compelling" (1998: 276). 


\section{RELIANCE ON INDIGENIZATION}

There are two reasons why adaptation might be necessary or desirable. Frames may be adapted to increase their appeal to those outside the movement. As discussed above, the historical context of pre-handover Hong Kong made this unnecessary. However, frames may also be adapted to fit the worldview of movement participants and attract followers. In the female inheritance movement, indigenization of the master rights frame was an important part of securing support, particularly of local women's groups.

Many Hong Kong women's groups were founded specifically to localize American and European feminism. AAF, for example, was founded "to bring together people who speak our language and share a similar background" and "work within our own culture" (AAF founder quoted in Choi 1995: 95). In discussing the role of the Hong Kong Women Christian Council, one of the founding members emphasized the importance of local leadership: "[We are] a local Christian women's group, not the expatriates. If they join us, then they may play a supporter's role ... but we have a local basis" (quoted in Choi 1995: 97).

Given the strength of concern about localization, it is unlikely that Hong Kong women's groups would have participated in a movement they saw as foreign-led. In the female inheritance movement, this concern played out through indigenization, the use of local symbols to express international conceptions of rights and gender equality. The women's groups, for example, interchanged critiques of patriarchy with critiques of feudalism. During the rally outside the Legislative Council during the October motion debate, demonstrators shouted "Down with feudal traditions!" (Hong Kong Standard, 14 Oct. 1993). Feudalism, a term associated with pre-revolutionary China, functioned as shorthand for gender inequality and patriarchy ${ }^{28}$ Anti-feudalism was the theme of the May 4, 1994 demonstration outside the Legislative

Council, a conscious homage to China's May 4th movement (Cheung 1994: 7) ${ }^{29}$ Discussions of feudalism also touched on Confucianism. One women's group wrote that "depending on fathers, husbands and children is exactly what the 'three subordinations' teaches in feudal society" and is in opposition "to the principle of independence for women" (quoted in Lee 2000: 250).

References to feudalism, May 4th, and Confucianism were a way to put gender equality in a regional historical context. In response to claims that foreign conceptions of rights did not apply to Asia, Hong Kong women's groups used references to Chinese history to implicitly argue that a rights framework was not a foreign import, but a strand of Chinese culture. By situating their claims in pre-1949 Chinese history, women's groups claimed rights arguments for themselves. Indigenization offered a way for women's groups to tap the power of rights language while feeling comfortable that they were working within their own culture.

References to feudalism and May 4th were largely ignored outside of the women's movement because the rights framework was already legitimate by virtue of its relevance to the debate over post-1997 freedoms. Local symbols, however, were important in other ways. Symbols of indigenous culture, like Hakka hats, helped bolster the legitimacy of the indigenous women and attract media attention. Hakka hats connoted both "rural" and "hard-working" to Hong Kong residents because Hakka women are known as hard working farmers. The hats, particularly when combined with folk laments, visually conveyed the local authenticity of the women's rural backgrounds and made it difficult for opponents to claim that the female inheritance movement was dreamed up by foreign-influenced urban feminists without indigenous support.

\section{TRANSLATORS: AN AD HOC STRUCTURAL ADAPTATION}

Typically, participants in social movements see the issue in a way that is "congruent and complementary" to the master frame, a process known as frame alignment (Snow and Benford 1986: 475). Most often, this occurs organically as participants' understanding of the problem changes through movement participation. The most unusual feature of the female inheritance 
movement was that the indigenous women themselves saw their claims in terms of kinship obligations, not rights. Although this kinship frame rarely, if ever, surfaced in public, it was able to co-exist with a rights frame only because of the roles played by translators.

The critical insight here comes from Eliza Chan's master's thesis in anthropology at the Chinese University of Hong Kong (1995). Chan spent significant time with the indigenous women during the movement and focused on how these women perceived events at the time. She persuasively argues that most of the indigenous women saw their claims in terms of kinship. Most of the women did not criticize the lineage system itself but blamed particular relatives who reneged on their kinship obligations to provide them financial and emotional support in lieu of their father's land. One woman was most angry that her relatives had failed to keep in touch with her. They should not have forgotten that she was her father's "root and sprout" and "flesh and blood." If she had inherited, she said, she would have allowed her rela-tives to live in her father's house as long as they maintained close ties with her (Chan 1995: 88-89).

When the women did make inheritance claims, they justified inheritance rights on the basis of ties to their father. In telling their stories, several of the women emphasized the role they played in their father's funerals (Chan 1995: 82-85). Because they had been filial, affectionate daughters, they argued, they were entitled to inherit. ${ }^{30}$ In some sense, the women reinforced the patrilineal system even as they asserted their rights (Chan 1995: 97). Only one of the women in the Residents Committee had a brother. The rest of the women were all "last of line" daughters (jiefangnu) and, as a result, their father's land was inherited by distant male relatives. ${ }^{31}$ In Chan's interviews, most of the women said they would have been willing to give up their inheritance rights if they had brothers (Chan 1995: 72). ${ }^{32}$

In theoretical terms, most of the indigenous women retained a domain-specific frame throughout the movement. Domain-specific frames, limited to a particular arena, require recognition that "a domain previously taken for granted is reframed as problematic and in need of repair" (Snow and Benford 1986: 474). In contrast, global interpretive frames, like the rights frame used in the female inheritance movement, have a much broader scope. They provide a template to interpret "events and experiences in a new key" (Snow and Benford 1986: 475). In the female inheritance movement, the indigenous women's kinship frame aligned with the movement frame (they recognized that change was needed), but they never experienced the "thoroughgoing conversion" associated with the transformation of a global interpretive frame (Snow and Benford 1986: 475).

This was possible because of the structural role played by the Residents Committee and two individual translators: Cheng and Wong. Although the Hong Kong Federation of Women's Centres claimed that the "women took all the initiatives by themselves while the Centre just concentrated on providing resources and support," the process was more complicated (Hong Kong Federation of Women's Centres 1994: 20; see also Lui 1997: chapters 4 and 20). Chan describes how the social workers on the Residents Committee helped the indigenous women make their stories more powerful by framing them in terms of gender equality and rights (1995: 119). The solution was not mediation and a more equal division of property, but a broadly ranging change to an unfair law. The outsiders in the group groomed the women in dealing with the media. On several occasions, they "drilled" the women, training them to keep their stories short and quotable, avoiding slang and speaking with sufficient detachment (Chan 1995: 120). The women practiced responding to tough questions like: "There are some women in the New Territories who said that they do not need the rights of inheritance. Why do you insist on it?" (Chan 1995: 117-119; see also Chan interview 2003 and Cheng interview 2003). In addition, the Residents Committee helped the women branch out into different modes of expression, creating dramas and songs to illustrate the injustice of male-only inheritance. A labor organizer, one of the outside voices in the group, became the "stage director" for the drama. As one interviewee put it, "she put together elements to strike those cameras," like suggesting that the women dress in traditional Hakka clothes (Chan interview 2003; Cheng interview 2003). ${ }^{33}$ 
It would be easy to believe that the indigenous women lost control of their stories and were exploited for political change, as has occurred elsewhere (Keck and Sikkink 1998: 20). The reality, however, is more nuanced. While the outsiders on the Residents Committee helped the women present themselves to the outside world, the women themselves played an active role in shaping the strategy. The idea of rewriting lyrics to indigenous songs, for example, came from the women (Chan 1995: 108; Cheng interview 2003). The women also had a voice in the wider women's movement through the chairperson of the Residents Committee, Lai-sheung Cheng, who attended meetings of a coalition of women's groups. Perhaps most importantly, the women spoke for themselves. While the outside members of the Residents Committee coached the women, they also felt strongly that the women should have their own voice (Chan 1995: 117; Wong interview 2003).

\section{Translation, Not Transformation}

As the indigenous women learned to tell their stories differently, the way they thought about those stories also shifted to some degree. In the beginning, the women were hoping for outside intervention from either the Legislative Council or the Heung Yee Kuk to adjudicate their individual cases (Wong interview 2003) ${ }^{34}$ Through the Residents Committee, however, the women found others with similar stories and created a collective identity that, as Gamson predicts, blurred individual and collective interests (Gamson 1992: 57). Slowly, the women came to realize that the law needed to be changed. This domain-specific frame transformation (or move away from the "appeal to Beijing" strategy) was an essential precondition of the indigenous women's participation in the broader inheritance movement. ${ }^{35}$

Mapping a similar transformation in the women's global interpretive frame is more problematic. Clearly, the indigenous women had a strong sense of justice or they would not have come forward to push their claims. The Hakka mountain song, one of the few products the indigenous women definitely helped create, frames female inheritance in terms of fairness. The first two lines of the song show an awareness that the indigenous women are an oppressed group with common concerns: "Female indigenous women are the most unfortunate people / This world is unfair to them" (Chan 1995: 98). The second two lines go further, asking the Legislative Council for redress: "The Hong Kong society is unjust / I hope that the Legislative Councilors will uphold justice" (Chan 1995: 98).

Yet an internal moral compass did not mean that the women fully incorporated the master rights frame. Consciousness is a slippery, unquantifiable concept, but the women seem to have fallen along a spectrum from those who adopted a largely kinship-based perception of the problem to those for whom the rights frame predominated. Over the course of the movement one woman learned to talk about her story using terms like "gender discrimination" and "injustice," vocabulary that she literally did not know before joining the Residents Committee (Chan 1995: 146).

Overall, however, it is likely that references to rights and gender equality in documents jointly written by the Residents Committee were not introduced by the indigenous women themselves. In an article published in the Hong Kong Federation of Women's Centres Annual Report, for example, the Residents Committee calls the denial of female inheritance "a centurylong discriminatory barrier to the indigenous women's basic rights" (Hong Kong Federation of Women's Centres 1994: 88). Another submission to the Legislative Council talks about the "inherent right" to succession and mentions "the protection to women that has been laid down in the United Nations Universal Declaration of Human Rights" (Anti-Discrimination Female Indigenous Residents Committee 1994). Given the unfamiliarity of rights language and the illiteracy of the majority of the indigenous women, these articles and statements were probably guided by Linda Wong or the other outsiders on the Residents Committee. ${ }^{36}$

Another sign that the women did not develop a new global interpretive frame was their frustration when their stories were subsumed by the larger themes of gender equality or anti- 
discrimination (Chan 1995: 146; Cheng interview 2003). Nor did the indigenous women continue to fight for rights after female inheritance movement ended. Despite one woman's statement that "Now and after [the handover in] 1997, I will continue to bravely stand up and fight for the rights of indigenous women," the indigenous women dropped out of the women's movement after the NTL(E)O was passed (Hong Kong Women Christian Council 1995: 126; interviews). No doubt the women were tired of fighting, but this is also a sign that they saw their problems primarily as violations by particular male relatives, not as part of a larger struggle for gender equality.

Lack of frame transformation is unusual in the social movement literature. More commonly, an activist's worldview is fundamentally transformed through participation in a movement. McCann (1994), for example, sees participation in the pay equity movement as lifechanging event that altered the "hearts, minds and social identities" of participants by transforming their "understandings, commitments and affiliations" (230). As one woman put it, "I learned feminism through this thing" (264). Rothman and Oliver (1999: 44) similarly see frame alignment in the anti-dam movement in southern Brazil as a "wholesale reworking of the activists own understandings."

In this case, the indigenous women were able to sidestep wholesale transformation through the services of translators who publicly framed the women's stories in terms of rights. For this story, the two most important translators were Lai-sheung Cheng and Linda Wong. ${ }^{37}$ Both women were able to discuss female inheritance either in terms of obligation and responsibility (the kinship frame) or discrimination and gender equality (the rights frame), likely because they saw the issue in multiple terms from the start. Their ability to switch between frames held the coalition together. The indigenous women were able to participate in a rights-based movement, even if they were unfamiliar with rights language. The wider movement could utilize indigenous women's stories, even if urban feminists did not see the primary problem as callous male relatives. The translators served as a bridge, ensuring that urban and rural participants could speak to each other and work together.

Cheng was the official spokesperson for the Residents Committee because she was the person most comfortable talking about female inheritance in terms of discrimination, equality and rights as well as the person most comfortable talking to the press. In one interview, she said clearly "what I am fighting for is sexual equality" (The Sunday Telegraph, 24 Oct. 1993). At another point, she said that if the government refused to change the law, they "would be violating the Bill of Rights" (Hong Kong Standard, 14 Oct. 1993). In contrast, another indigenous woman's critique of the New Territories Ordinance was limited to the fact that "the legislation does not take care of situations where families do not have any sons, which is my case" (South China Morning Post, 25 Feb. 1993).

Although she did not have a formal leadership title, Linda Wong was another critical link between the indigenous women and the broader movement. The women were able to tell their stories in the Legislative Council because Linda Wong created the opportunity and showed them how to do it. With the help of other outsiders on the Residents Committee, she helped frame the women's stories in terms of equality and rights so that they were politically salable. Unlike the indigenous women, Wong had experience in activism and, like the other outsiders, had a good idea what the media and the public would find appealing. The carefully orchestrated dramas and songs had, in the words of one participant, a "symbolic meeting" that "became an icon for the whole movement" (Chan interview 2003). Wong also literally translated the Cantonese and Hakka used by the indigenous women into English, ensuring that the women's stories reached a wider audience and were taken seriously by elites.

The literature on cross-national diffusion of frames assumes that diffusion requires some degree of identification or similarity between adopter and transmitter (Strang and Meyer 1993: 487; McAdam 1995: 237; Snow and Benford 1999: 24). In the female inheritance movement, there were multiple transmitters of rights language and multiple adopters. ${ }^{38}$ Hong Kong 
women's groups, the public and the legislative council all endorsed some version of a rights frame. At the same time, translators offered an ad hoc structural adaptation to the fact that the indigenous women never entirely shifted to seeing their problem in global rights language. By buffering the indigenous women from the rights framework, translators lowered the bar for identification and lessened the potential disconnect between the indigenous women and their allies. Just as indigenization bridged the distance between a master rights frame and the local self-image of Hong Kong women's groups, translators closed the gap between the indigenous women's private perception of the problem and the public framing of it.

\section{CONCLUSION}

The female inheritance movement shows the importance of looking within social movements at interactions between groups and individuals. Diffusion is not an outcome, but a process by which participants pick up and modify ideas, structures and tactics. The extent of modification, I've suggested here, is variable and ranges from adoption to full adaptation.

In part, attitudes towards foreign imports determine where a movement falls on the adoption-adaptation continuum. The difference between the changes wrought to MarxismLeninism through Maoism (a classic example of adaptation) and the relatively static rights frame imported by the female inheritance movement shows a close relationship between innovation and attitudes towards the outside world. Mao came to power at a time of extreme nationalism, when all things Western were viewed with distrust and distaste. In an indication of the zeitgeist, a group of ten leading professors published a declaration in 1935 rejecting "wholesale Westernization" and demanding "a cultural construction on the Chinese basis" (quoted in Wylie 1980: 21). Maoism, a blend of Marxism and nationalism, was born out of Mao's desire to arrive at an ideology that would silence his critics. In contrast, 1993 Hong Kong was far friendlier to foreign ideas. If anything, rights were associated with civil liberties, a welcome ideal in the prehandover years. Indigenization was more than sufficient to garner support and, ultimately, change the law.

The female inheritance movement also suggests that where there is diffusion, there are translators - people who introduce new concepts and adapt them to the extent necessary to make them locally compelling. By helping the indigenous women see their problem as a broader question of rights, translators neutralized potential pressure to negotiate a new frame based on kinship. The female inheritance movement is, of course, only one case study, but I would expect to find translators in other movements.

For those on the lookout, translators are easily identifiable. They are the select few who flip between frames as easily as they move between audiences. Like Tarrow's "rooted cosmopolitans," they are anchored in a local context, but reach outside that context to tap global frames and find external allies (2005). Often, they are part of a mobile, global corps who travel regularly, read foreign books and journals and hold degrees from foreign universities (Tarrow 2005: 83). They are accustomed to global rights language and familiar with movements elsewhere. This international awareness is a major asset in frame building and, as a result, translators are often movement leaders. Always, they play a pivotal role in bringing together a powerful global frame with the grassroots stories integral to movement success.

\section{NOTES}

\footnotetext{
${ }^{1}$ Hong Kong is divided into four main areas: Hong Kong Island, Kowloon, the New Territories and the Outlying Islands. The New Territories are north of Kowloon and border Mainland China.

${ }^{2}$ In Hong Kong, "indigenous" encompasses anyone who can trace their ancestry back to before the British took over the New Territories in 1899. A political as well as a cultural claim, indigenous residents include Cantonese, Hakka and Punti speakers who settled in the New Territories over a period of centuries before the British arrived (Watson 1985).
} 
${ }^{3}$ The Heung Yee Kuk, founded in 1926, is the highest tier of village representative organizations (Chan 2003: 67, 87). The Kuk is a conservative body that, since the late 1950s, has lobbied for increased compensation for land used for development (Chan 2003: 71). Most Kuk members are also major landowners in the New Territories.

4 "Hakka hats" is the colloquial term for the oversized hats worn by farmwomen. It is not clear if these hats are exclusively worn by Hakka women or just associated with farm work.

${ }^{5}$ This article is a further meditation on ideas and themes developed with Sally Merry in Merry and Stern (2005). Merry is currently a Professor of Anthropology and Law and Society at New York University.

${ }^{6}$ Diffusion is not a new process. Soule and Tarrow (1991: 49) note that German mobs carried the French tricolor during the revolution of 1848 .

${ }^{7}$ See also McAdam (1995) as well as Chabot and Duyvendak (2002).

${ }^{8}$ This definition draws on Kriesi et al. (1995: 185-186) and their discussion of social movements features amenable to diffusion across boarders.

${ }^{9}$ Snow and Benford (1999) distinguish between three types of diffusion processes: reciprocation (both the adopter and transmitter are actively engaged), adaptation (only the adopter is actively engaged) and accommodation (only the transmitter is actively engaged).

${ }^{10}$ On the importance of leadership in social movements see Aminzade, Goldstone, and Perry (2001).

${ }^{11}$ This account of Lai-sheng Cheng's story relies on Chan (1995), media sources, and an interview with Cheng in June 2003.

${ }^{12}$ Governor Patten did, in fact, reply, although he did not take any action (Cheng interview 2003).

${ }^{13}$ The staff of Oriental Daily knew Wong because the Hong Kong Federation of Women's Centres was lobbying for a Women's Commission. It was a high-profile project and Linda Wong's name was often in the paper (Wong interview 2003)

${ }^{14}$ Several women also contacted Cheng after they saw her name and story in a Chinese newspaper, Wah Kui Daily (Cheng interview 2003). It is not clear, however, if these women attended the first meeting with Linda Wong or joined the group later.

${ }^{15}$ Part II, section 13 of the New Territories Ordinance states: "In any proceedings in the High Court or the District Court in relation to land in the New Territories, the court shall have the power to recognize and enforce any Chinese custom or customary right affecting such land" (Wesley-Smith 1994: 209, note 33).

${ }^{16}$ By the time the news broke, the Hong Kong Council of Women had already informed the government of the problem. In July 1993, the government started automatically exempting all new grants of lands (with the exception of land grants to indigenous villagers) from the New Territories Ordinance (South China Morning Post, Nov. 3, 1994)

${ }^{17}$ Timelines of the female inheritance movement say that the Anti-Discrimination Female Indigenous Residents Committee was founded on November 27, 1993 (Wong 2000: 299; Chan 1995: 47). However, Reverend Fung congratulated the newly founded "Anti-Discrimination Committee of the Indigenous Women of the New Territories" during the October 13, 1993 motion debate (Hong Kong Hansard 1993: 233). Most likely, the group was formally founded on November 27, but was already meeting regularly before then.

${ }^{18}$ The number of members of the Residents Committee is unclear. Chan (1995) cites six active members, although one is a news reporter without a grievance (39). Wong and Chan (interview 2003) list seven core members. Most likely, there was some flux over time. In addition to Wong and the indigenous women, others attending Residents Committee meetings included a representative from the Association from the Advancement of Feminism (AAF), a Radio Television Hong Kong reporter, an Anthropology graduate student and a labor organizer.

${ }^{19}$ As defenders of tradition, the Kuk placed emphasis on being Chinese. One song often sung at demonstrations was "The Brave Chinese," renamed "The Brave New Territories People" (Chan 1998: 47). Being Chinese also meant renewed attention to the anti-colonial strands of indigenous history. In April 1994, 1,000 villagers gathered to commemorate an 1899 uprising against the British at Tai Po (Chan 1998: 45; see also South China Morning Post, 18 April 1994). Ironically, it was the first time the uprising was ever publicly commemorated (Chan 1998: 46).

${ }^{20}$ All New Territories men are eligible for this once-in-lifetime land grant, even those overseas. The original aim of the policy was to replace temporary housing and allow for natural growth in the New Territories (for more information, see Hopkinson and Lei 2003; Chan 1999: 238-240).

${ }^{21}$ This was a survey of all of Hong Kong.

${ }^{22}$ Although it is difficult to remember in hindsight, there was no reason male-only inheritance had to be addressed through legislative change. In 1993, five indigenous women applied for legal aid to sue for equal inheritance. Their request was denied, but their efforts show that the inheritance issue could have been settled by the courts (South China Morning Post, 23 Oct. 1993). Inheritance was only resolved through legislation because of the Hong Kong Council of Women's discovery that female inheritance was illegal throughout the New Territories, not just in the villages (Jones interview 2003).

${ }^{23}$ There were also conservative women's groups, such as the Hong Kong Federation of Women, which favored a more gradual approach. In a statement, the Federation wrote "we aim at progress without upsetting stability" (Hong Kong Federation of Women 1994). Peggy Lam, a founding member of the Hong Kong Federation of Women as well as a legislative councilor, argued that haste to pass the amended NTL(E)O caused anxiety and conflict that could have been avoided (Hansard 1994: 4548-4549).

${ }^{24}$ Some later criticized the female inheritance movement because it failed to offer a fundamental challenge to patriarchy (Lui 1997: chapter 4, 22).

${ }^{25}$ In 1991, eighteen (of sixty) Legislative Council seats were elected for the first time. The 1992 reform package 
broadened the electorate by lowering the voting age to 18 and provided for the direct election of half the Legislative Council.

${ }^{26}$ A great deal of literature has examined the connection between democratization and increased support for women's rights. See Fischler (2000), Lui (1997), Tong (1994) and Tong (1999).

${ }^{27}$ Keck and Sikkink (1998) call the use of international pressure to push domestic change a boomerang effect (11-12). Sperling (2001) notes that the Russian women's movement used language from international documents for this reason (1163)

${ }^{28}$ The Hong Kong Council of Women's ICCPR report also makes reference to feudalism. The report calls male-only inheritance a "feudal" result of a patriarchal Confucian social order (Howarth et al. 1991: 17 and 13).

${ }^{29}$ The May Fourth movement (1919) was a move away from Confucian tradition towards gender equality, democracy, vernacular literature and reliance on science.

${ }^{30}$ In some cases, affection and kinship were valid criteria for female inheritance. Chan (1997) discusses a case from the 1970s in which a village council ruled that a daughter could become trustee of her father's land because she was the person closest to her father (155-159).

${ }^{31}$ For a more extended discussion of what it means to be a "last of line" daughter, see Chan 1995: 40, 60-3.

${ }^{32}$ It is not clear from her thesis if Chan asked all the women this question. Chan (1995) writes: "When I interviewed the women, they expressed their willingness to give up their inheritance rights, should they have brothers in their immediate families" (72). One of the members of the Anti-Discrimination Female Indigenous Residents Committee thought that there was a difference in attitude between the older and younger women. The older women's claims did not involve property while the younger women wanted a fair share of their father's land (Chan interview 2003).

${ }^{33}$ In creating the dramas, the organizers were responding to the stereotypes they knew the media wanted to see. The media discussed female inheritance in terms of dichotomies. The Kuk were portrayed as traditional, rural and male while the female inheritance coalition was urban, modern and female (Chan 1995: 50). For the most part, the indigenous women were seen as victims of "tradition" and lineage hegemony (Chan 1995: 100). One TV series broadcast during the movement depicted the lineage system as a "living fossil" of Chinese tradition (Chan 1995: 107). In 1994, these dichotomies were deeply entrenched. The media had long seen the New Territories as a bastion of outdated tradition. In a 1986 documentary on New Territories life, the narrator closes by saying "traditional modes of thinking vastly out of step with the modern world are still deep rooted in the hearts of indigenous villagers in the New Territories" (RTHK 1986).

${ }^{34}$ In a 2003 interview, Cheng said the women knew that the law had to be changed from the start. I believe Cheng was reflecting her own personal viewpoint rather than the attitude of the group.

${ }^{35}$ The "appeal to Beijing" strategy has a long historical precedent. In the Qing dynasty, going to Beijing to beat the grievance drum was one way to address local injustice. The emperor generally took these appeals seriously because of the risks and rigors of the journey (Ocko 1988: 305-306). In modern China, Thireau, and Linshan (2003) show that Letters and Visits Offices provide a similar way to appeal to the central government and receive redress.

${ }^{36}$ Of the seven indigenous women who formed the core of the Residents Committee, four were illiterate. None were educated beyond secondary school (Wong and Chan interview 2003).

${ }^{37}$ Merry and Stern (2005) also discuss Anna Wu's role as a translator. There may also have been other translators. The goal here is not to provide an exhaustive list of translators, but to highlight the important role they played.

${ }^{38}$ Thanks to one of Mobilization's reviewers for helping clarify this point.

\section{REFERENCES}

Aminzade, Ronald, Jack A. Goldstone, and Elizabeth J. Perry. 2001. "Leadership Dynamics and Dynamics of Contention." Pp. 126-154 in Silence and Voice in the Study of Contentious Politics, Ronald Aminzade et al. eds. Cambridge, England: Cambridge University Press.

Association for the Advancement of Feminism. 1993. "New Territories Women Denied Right to Inherit." Women's News Digest 29: 13-14.

Best, Joel, ed. 2001. How Claims Spread: Cross-National Diffusion of Social Problems. New York: Aldine de Gruyter.

Chabot, Sean, and Jan Willem Duyvendak. 2002. "Globalization and Transnational Diffusion Between Social Movements: Reconceptualizing the Dissemination of the Gandhian Repertoire and the "Coming Out" Routine." Theory and Society 31: 697-740.

Chabot, Sean. 2000. "Transnational Diffustion and the African American Reinvention of the Gandhian Repertorie." Mobilization: An International Journal 5: 201-216.

Chan, Eliza Chong-lai. 1995. "Negotiating Daughterhood: A Case Study of the Female Inheritance Movement in the New Territories, Hong Kong." Masters in Anthropology thesis, Chinese University.

Chan, Eliza. 1997. "Jyuht Fong Neuih: Female Inheritance and Affection." Pp. 174-197 in Hong Kong: The Anthropology of a Chinese Metropolis, Grant Evans and Maria Tam, eds. Honolulu: University of Hawai'i Press. 
Chan, Selina Ching. 1998. "Politicizing Tradition: The Identity of Indigenous Inhabitants of Hong Kong." Ethnology 37: 39-54.

. 1999. "Colonial Policy in a Borrowed Place and Time: Invented Tradition in the New Territories of Hong Kong." European Planning Studies 7: 231-242.

- 2003. "Memory Making, Identity Building: The Dynamics of Economics and Politics in the New Territories of Hong Kong." China Information 17: 66-91.

Cheung, Choi Wan. 1994. "New Territories Indigenous Women Reclaimed Inheritance Rights." Women's News Digest 32-33: 6-7.

Choi Po-king. 1995. "Identities and Diversities: Hong Kong Women's Movement in 1980s and 1990s." Hong Kong Cultural Studies Bulletin 4: 95-103.

Della Porta, Donatella, and Hanspeter Kriesi. 1999. "Social Movements in a Globalizing World: An Introduction." Pp. 3-22 in Social Movements in a Globalizing World, Donatella della Porta, Hanspeter Kriesi and Dieter Rucht, eds. New York, NY: Saint Martin's Press.

Diamant, Neil J. 2005. "Hollow Glory: The Politics of Rights and Identity Among PRC Veterans." Pp. 131-160 in Engaging the Law in China: State, Society and Possibilities for Justice, Neil J. Diamant, Stanley B. Lubman, and Kevin O’Brien, eds. Stanford, CA: Stanford University Press.

Fischler, Lisa Collynn. 2000. "Women at the Margin: Challenging Boundaries of the Political in Hong Kong." Ph.D. dissertation, University of Wisconsin.

Foot, Rosemary. 2000. Rights Beyond Borders: The Global Community and the Struggle Over Human Rights in China. Oxford, England: Oxford University Press.

Gamson, William, and David Meyer. 1996. "Framing Political Opportunity." Pp. 275-290 in Comparative Perspectives on Social Movements: Political Opportunities, Mobilizing Structures and Cultural Framings, Doug McAdam, John McCarthy, Mayer Zald, eds. New York: Cambridge University Press.

Hart, Stephen. 1996. "The Cultural Dimension of Social Movements: A Theoretical Assessment and Literature Review." Sociology of Religion 57: 87-101.

Hong Kong Federation of Women. 1994. Statement on Conflict Arising from New Territories Women's Right of Succession. Unpublished.

Hong Kong Federation of Women's Centres. 1994. Annual Report: 1993-1994. Hong Kong, China: Hong Kong Federation of Women's Centres.

Hong Kong Hansard. 1993. Proceedings of the Legislative Council. <www.legco.gov.hk/yr93-94/ englihs/lc_sitg/hansard/h931013.pdf $>$.

- 1994. Proceedings of the Legislative Council. <www.legco.gov.hk/yr9394/English/lc_sitg/ hansard/h940622.pdf>

Hong Kong Women Christian Council ed. 1995. Uncertain Times: Hong Kong Women Facing 1997. Hong Kong, China: Hong Kong Women Christian Council.

Hopkinson, Lisa, and Mandy Lao Man Lei. 2003. Rethinking the Small House Policy. Hong Kong, China: Civic Exchange.

Howarth, Carla, Carol Jones, Carole Petersen and Harriet Samuels. 1991. Report by the Hong Kong Council of Women on the Third Periodic Report by Hong Kong under Article 40 of the International Covenant on Civil and Political Rights. Hong Kong, China: Hong Kong Council of Women.

Keck Margaret E., and Kathryn Sikkink. 1998. Activists Beyond Borders: Advocacy Networks in International Politics. Ithaca, NY: Cornell University Press.

Kriesi, Hanspeter, Rudd Koopmans, Jan Willem Duyvendak, and Marco G. Giuni, eds. 1995. New Social Movements in Western Europe: A Comparative Analysis. Minneapolis, MN: University of Minnesota Press.

Lee, Ching Kwan. 2000. "Public Discourses and Collective Identities: Emergence of Women as a Collective Actor in the Women's Movement in Hong Kong." Pp. 227-257 in The Dynamics of Social Movement in Hong Kong, Stephen Wing, Kai Chiu, and Tai Lok Lui, eds. Hong Kong, China: Hong Kong University Press.

Lee, Martin C.M. 1996. "The Rule of Law in Hong Kong: Implications for 1997." The Annals of the American Academy of Political and Social Science 547: 165-171.

Loh, Christine. 1997. Inheritance Rights of Indigenous Women of the New Territories. http://www. christineloh.bizland.com/cloh/vz_mainframe.htm

Lui, Yuk-lin. 1997. "The Emergence and Development of the Feminist Movement in Hong Kong from the Mid-1980s to the Mid-1990s." Masters thesis, Government and Public Administration, Chinese University. 
Meisner, Maurice. 1999. Mao's China and After: A History of the People's Republic. New York, NY: The Free Press.

Merry, Sally Engle, and Rachel E. Stern. 2005. "The Female Inheritance Movement in Hong Kong: Theorizing the Local/Global Interface." Current Anthropology 46 (3): 387-409.

McAdam, Doug. 1989. "The Biographical Consequences of Activism." American Sociological Review 54: 744-760.

_ 1995. “'Initiator' and 'Spin-off' Movements: Diffusion Processes in Protest Cycles.” Pp. 217-239 in Repertoires and Cycles of Collective Action, Mark Traugott ed. Durham, NC: Duke University Press.

McAdam, Doug, and Dieter Rucht. 1993. "The Cross-National Diffusion of Movement Ideas.” Annals of the American Academy of Political and Social Science 528: 56-74.

McAdam, Doug, and William H. Sewell Jr. 2001. "It's About Time: Temporality in the Study of Social Movements and Revolutions.” Pp. 89-125 in Silence and Voice in the Study of Contentious Politics, Ronald Aminzade, eds. New York: Cambridge University Press.

McCann, Michael. 1993. "Reform Litigation on Trial." Law and Social Inquiry 17: 715-43. . 1994. Rights At Work. Chicago, IL: Chicago University Press.

Ocko, Jonathan. 1988. "I'll Take It All the Way to Beijing: Capital Appeals in the Qing." The Journal of Asian Studies. 47 (2): 291-315.

O’Brien, Kevin J. 1996. "Rightful Resistance.” World Politics 49 (1): 31-55.

O'Brien, Kevin J., and Lianjiang Li. 2005. "Popular Contention and its Impact: Evidence from the Chinese Countryside." Comparative Political Studies 38 (3): 235-259.

. 2004. "Suing the Local State: Administrative Litigation in Rural China." The China Journal 51: 75-96.

Petersen, Carole. 1996. "Equality as a Human Right: The Development of Anti-Discrimination Law in Hong Kong." Columbia Journal of Transnational Law 34: 335-387.

Petersen, Carole, and Harriet Samuels. 2002. "The International Convention on the Elimination of All Forms of Discrimination Against Women: A Comparison of its Implementation and the Role of Non-Governmental Organizations in the United Kingdom and Hong Kong." Hastings International and Comparative Law Review 26:1-51.

Rothman, Franklin Daniel, and Pamela E. Oliver. 1999. "From Local to Global: The Anti-Dam Movement in Southern Brazil, 1979-1992." Mobilization 4(1): 41-57.

Scalmer, Sean. 2002. Reinventing Social-Movement Repertoires: The 'Operation Gandhi' Experiment. $<\mathrm{http}$ //eprints.anu.edu.au/archive/00002023/01/scalmerpaper.pdf $>$.

. 2002. "The Labor of Diffusion: The Peace Pledge Union and the Adaptation fo the Gandhian Repertoire.: Mobilization: An International Journal 7: 269-286

Selby, Stephen. 1991. "Everything You Wanted to Know About Chinese Customary Law (But Were Afraid to Ask)." Hong Kong Law Journal 21: 45-77.

Scott, James. 1990. Domination and the Arts of Resistance. New Haven, CT: Yale University Press.

Snow, David, Robert Benford, E. Burke Rochford and Steven Worden. 1986. "Frame Alignment Processes, Micromobilization and Movement Participation." American Sociological Review 51: 464-81.

Snow, David, and Robert Benford. 1999. "Alternative Types of Cross-National Diffusion in the Social Movement Arena.” In Social Movements in a Globalizing World, Donatella della Porta, Hanspeter Kriesi and Dieter Rucht, eds. New York, NY: Saint Martin's Press.

- 2000. "Framing Processes and Social Movements: An Overview and Assessment." American Review of Sociology 611-39.

Soule, Sarah A., and Sidney Tarrow. 1991. Acting Collectively, 1847-1849: How the Repertoire of Collective Action Changed and Where it Happened. Prepared for the Annual Conference of the Social Science History Association, New Orleans.

Sperling, Valerie, Myra Marx Ferree, and Barbara Risman. 2001. "Constructing Global Feminism: Transnational Advocacy Networks and Russian Women's Activism.” Signs 26: 1155-86.

Strang, David, and John W. Meyer. 1993. "Institutional Conditions for Diffusion." Theory and Society 22 (4): 487-511.

Tarrow, Sidney. 1992. "Mentalities, Political Cultures and Collective Action Frames: Constructing Meanings Through Action.” In Frontiers in Social Movement Theory, Aldon D. Morris and Carol McClurg Mueller eds. New Haven, CT: Yale University Press.

. 1998. Power in Movement. Cambridge, England: Cambridge University Press.

. 2005. The New Transnational Activism. Cambridge: Cambridge University Press.

Thireau, Isabelle, and Hua Linshan. 2003. "The Moral Universe of Aggrieved Chinese Workers: 
Workers' Appeals to Arbitration Committees and Letters and Visits Offices." The China Journal 50: 83-103.

Thornton, Patricia. 2002. "Framing Dissent in Contemporary China: Irony, Ambiguity and Metonymy." The China Quarterly 160: 1019-35.

Tong, Irene. 1999. "Re-inheriting Women in Decolonizing Hong Kong." In Democratization and Women's Movements, Jill M. Bystydzienski and Joti Sekhon eds. Bloomington, IN: Indiana University Press. - 1994. "Women.” Pp. 367-387 in The Other Hong Kong Report 1994, Donald H. McMillen and Si-wai Man eds. Hong Kong, China: Chinese University Press.

. n.d.. "The Women's Movement in Hong Kong's Transition." Department of Politics and Public Administration, University of Hong Kong, Hong Kong.

Tsang Gar Yin, and Chi Kie Wan. 1994. "Campaign for Equal Inheritance Rights.” Women's News Digest 32-33: 8-13.

Watson, James L., ed. 1997. Golden Arches East: McDonald's in East Asia. Stanford, CA: Stanford University Press.

Watson, Rubie S. 1985. Inequality Among Brothers: Class and Kinship in South China. Cambridge: Cambridge University Press.

Wesley-Smith, Peter. 1995. Women's Rights Under Chinese Custom in Hong Kong. Prepared for the Congress on Folk Law and Legal Pluralism, Accra Conference, typescript.

—. 1994. The Sources of Hong Kong Law. Hong Kong, China: Hong Kong University Press.

Wong, Pik Wan. 2000. "Negotiating Gender: The Women's Movement for Legal Reform in Colonial Hong Kong." Ph.D.dissertation, University of California at Los Angeles.

Wu, Anna. 1993. Letter to the Members of the Bills Committee Considering the New Territories Land (Exemption) Bill. Unpublished letter.

Wylie, Raymond. 1980. The Emergence of Maoism. Stanford, California: Stanford University Press.

Yan, Yunxiang. 1997. "McDonald's in Beijing: The Localization of Americana." Pp. 39-76 in Golden Arches East: McDonald's in East Asia, James L. Watson, ed. Stanford, CA: Stanford University Press.

Zald, Meyer. 1996. "Culture, Ideology and Strategic Framing." Pp. 261-274 in Comparative Perspectives on Social Movements: Political Opportunities, Mobilizing Structures and Cultural Framings, Doug Mc Adam, John McCarthy, Mayer Zald, eds. New York: Cambridge University Press. 